\title{
Streptococcus mutans adherence to conventional and self-ligating brackets: an in vitro study
}

\author{
Murilo Fernando Neuppmann FERES ${ }^{1} \bowtie$ \\ (i) https://orcid.org/0000-0002-7185-544X \\ Fernanda VICIONI-MARQUES ${ }^{1}$ \\ (iD https://orcid.org/0000-0003-1741-3365 \\ Fábio Lourenço ROMANO ${ }^{1}$ \\ (i) https://orcid.org/0000-0003-1419-3520 \\ Marina Guimarães ROSCOE ${ }^{2}$ \\ (i) https://orcid.org/0000-0002-1670-4649 \\ Vinícius Matsuzaki de SOUZA4 \\ (i) https://orcid.org/0000-0002-3789-3303 \\ Aline Lira TORNERI ${ }^{3}$ \\ (i) https://orcid.org/0000-0002-1155-8048 \\ Bruno BUENO-SILVA 3 \\ (D) https://orcid.org/0000-0003-3275-5910
}

Submitted: March 02, 2020 - Revised and accepted: August 31, 2020

凶 murilo.feres@forp.usp.br

How to cite: Feres MFN, Vicioni-Marques F, Romano FL, Roscoe MG, Souza VM, Torneri AL, Bueno-Silva B. Streptococcus mutans adherence to conventional and self-ligating brackets: an in vitro study. Dental Press J Orthod. 2021;26(6):e212019.

(1) Universidade de São Paulo, Faculdade de Odontologia de Ribeirão Preto, Departamento de Clínica Infantil (Ribeirão Preto/SP, Brazil). (2) Universidade de São Paulo, Faculdade de Odontologia, Departamento de Biomateriais e Biologia Oral (São Paulo/SP, Brazil). (3) Universidade de Guarulhos, Programa de Pós-Graduação, Mestrado em Ortodontia (Guarulhos/SP, Brazil). (4) Private practice (Guarulhos/SP, Brazil). 


\section{ABSTRACT}

Introduction: Although self-ligating brackets presumably provide better hygiene conditions, no consensus has been reached so far. Objective: Therefore, the objective of this study was to evaluate, in an in vitro experimental design, the adherence of Streptococcus mutans (SM) in self-ligating and conventional brackets of different manufacturers and ligature types. Methods: Four commercial brands of maxillary premolar metal brackets were tested (Abzil ${ }^{\circledR}$; Morelli ${ }^{\circledR} ; 3 \mathrm{M}$ Unitek ${ }^{\circledR}$; and GAC $^{\circledR}$ ). Each one was subdivided into three groups, which varied according to the type of ligature and bracket model (metallic, elastic, and self-ligating), totalizing twelve groups, composed of six brackets each. Previously sterilized brackets were initially immersed in saliva for one hour, and subsequently washed and added in a bacterial suspension, maintained in aerobiosis for 72 hours. The adhered bacteria were then separated and quantified by colony forming units $(\mathrm{CFU} / \mathrm{mL})$ counting after 48 hours of growth. The groups were compared by Kruskal-Wallis and Dunn post-hoc tests $(p<0.05)$. Results: Regardless of the commercial brand, self-ligating brackets had significantly less CFU/mL. However, according to comparisons performed within each commercial brand, only Abzil ${ }^{\circledR}$ self-ligating brackets had significantly lower biofilm adhesion. Among all of the self-ligating models, $\mathrm{GAC}^{\circledR}$ brackets presented the highest bacterial adhesion rate. Conclusions: Self-ligating brackets are likely to present lower rates of biofilm adhesion. Particularly, Abzil ${ }^{\circledR}$ and GAC ${ }^{\circledR}$ self-ligating brackets are less likely to accumulate biofilm. Although such results are derived from an in vitro study, practitioners might acknowledge findings concerning bacterial adhesion as one of the relevant features to be considered during bracket selection.

Keywordls: Orthodontic brackets. Biofilms. In vitro techniques. 


\section{RESUMO}

Introdução: Embora os braquetes autoligados presumivelmente proporcionem melhores condições de higiene, nenhum consenso foi alcançado até o momento. Objetivo: O objetivo do presente estudo foi avaliar, em um delineamento experimental in vitro, a aderência de Streptococcus mutans em braquetes autoligados e convencionais de diferentes fabricantes e tipos de ligaduras. Métodos: Quatro marcas comerciais de braquetes metálicos de pré-molares superiores foram testadas (Abzil ${ }^{\circledR}$; Morelli $^{\circledR} ; 3 \mathrm{M}$ Unitek ${ }^{\circledR}$; e GAC $\left.{ }^{\circledR}\right)$. Cada marca foi subdividida em três grupos, que variaram de acordo com o tipo de ligadura e o modelo do braquete (metálico, elástico e autoligado), totalizando doze grupos, compostos por seis braquetes cada. Os braquetes previamente esterilizados foram, inicialmente, imersos em saliva por uma hora, sendo posteriormente lavados e adicionados em uma suspensão bacteriana, mantida em aerobiose por 72 horas. As bactérias aderidas foram, então, separadas e quantificadas por contagem de unidades formadoras de colônias (UFC/mL) após 48 horas de crescimento. Os grupos foram comparados pelos testes post-hoc de Kruskal-Wallis e Dunn $(p<0,05)$. Resultados: Independentemente da marca comercial, os braquetes autoligados apresentaram significativamente menos UFC/mL. Porém, de acordo com as comparações realizadas dentro de cada marca comercial, apenas os modelos autoligados Abzil ${ }^{\circledR}$ apresentaram adesão de biofilme significativamente menor. Entre todos os modelos autoligados, os braquetes GAC ${ }^{\circledR}$ apresentaram a maior taxa de adesão bacteriana. Conclusões: Os braquetes autoligados provavelmente apresentam menores taxas de adesão do biofilme. Particularmente, os braquetes autoligados Abzil ${ }^{\circledR}$ e GAC ${ }^{\circledR}$ têm menor probabilidade de acumular biofilme. Embora tais resultados sejam derivados de um estudo in vitro, os clínicos podem reconhecer os achados relativos à adesão bacteriana como uma das características relevantes a serem consideradas durante a seleção dos braquetes.

Palavras-chave: Braquetes ortodônticos. Biofilme. Técnicas in vitro. 


\section{INTRODUCTION}

Even though orthodontic treatment brings important positive clinical and psychological effects, ${ }^{1-4}$ it is still likely to cause side effects, such as external root resorption and vertical reduction of the alveolar bone crest. ${ }^{5-9}$ In addition, orthodontic full-fixed appliances may also complicate oral hygiene, ${ }^{10,11}$ resulting in significant biofilm accumulation around the brackets bases. ${ }^{11-14}$ As a consequence, this accumulation can lead to negative alterations, such as gingivitis, ${ }^{15-17}$ enamel demineralization, including the formation of white spots lesions. ${ }^{15,20,21}$ Furthermore, orthodontic patients' installed biofilm profile may also be negatively altered, ${ }^{22-26}$ with simultaneous increase and deterioration of the microbiota quality ${ }^{25}$.

One of the most recent advances in Orthodontics refers to the development of the self-ligating brackets, originally designed to facilitate wire insertion and removal.27,28 These brackets feature an active or passive opening and closing device that ensures a safe and effective engagement of the wire into the bracket slot, ${ }^{29}$ with no need for metallic or elastic ligatures.

Although some authors have claimed that self-ligating brackets provide better hygiene conditions, ${ }^{29,30}$ no consensus has been found indicating that self-ligating brackets are actually more advantageous in this aspect. ${ }^{31}$ Therefore, the objective of this study was to evaluate, in an in vitro experimental design, 
the adherence of Streptococcus mutans (SM) in self-ligating and conventional brackets of different manufacturers and ligature types.

\section{MATERIAL AND METHODS}

\section{BRACKETS PREPARATION}

Four models of maxillary premolar metal brackets were tested in this study, i.e.: Abzil ${ }^{\circledR}$ (São José do Rio Preto, SP, Brazil), Morelli ${ }^{\circledR}$ (Sorocaba, SP, Brazil), 3M Unitek ${ }^{\circledR}$ (Monrovia, CA, USA), and $\mathrm{GAC}^{\circledR}$ (Bohemia, NY, USA).

For each of these commercial brands, two bracket models were selected (conventional and self-ligating brackets); and two types of ligatures - metallic $\left(0.025 \mathrm{~mm}\right.$; Morelli ${ }^{\circledR}$, Sorocaba/SP, Brazil) or elastic (gray color; Morelli ${ }^{\circledR}$, Sorocaba/SP, Brazil) were attached to the conventional brackets (Table 1). Thus, a total of twelve groups composed of six brackets each were formed (Fig 1). Each set of brackets was sterilized (Cristófoli ${ }^{\circledR}$, Curitiba/PR, Brazil) at $122^{\circ} \mathrm{C}$ for 15 minutes, and then reserved until the experiment. 

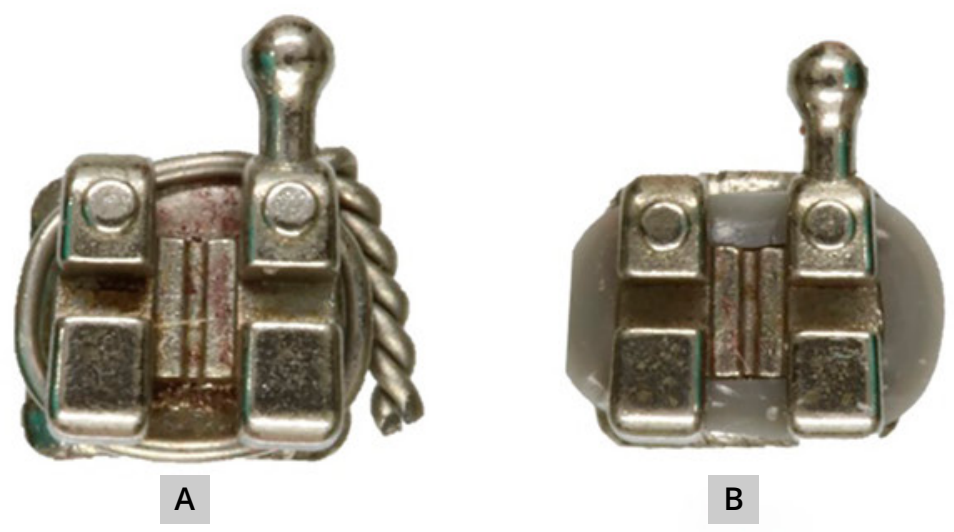

B

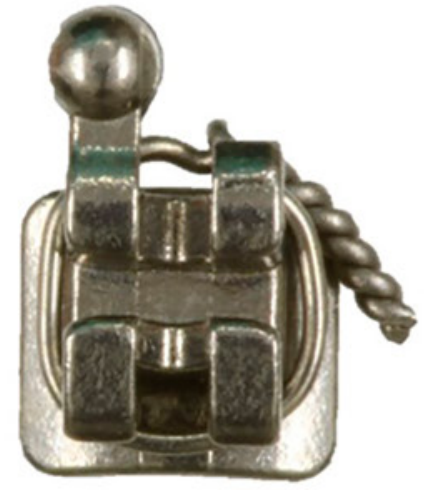

D

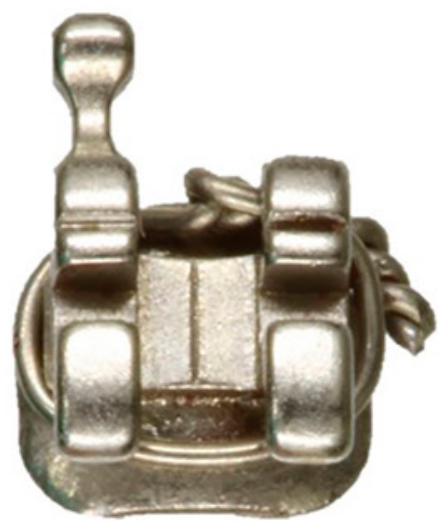

G

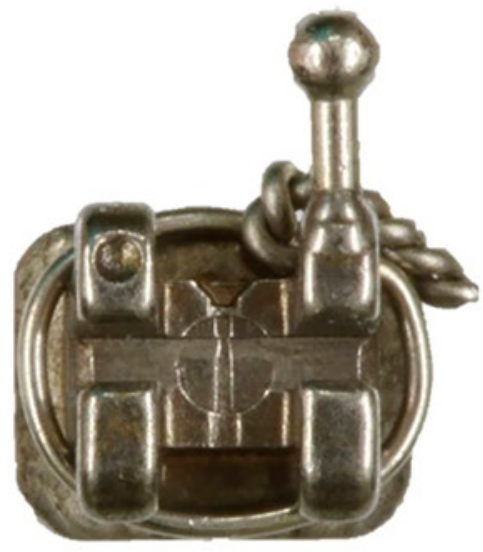

J

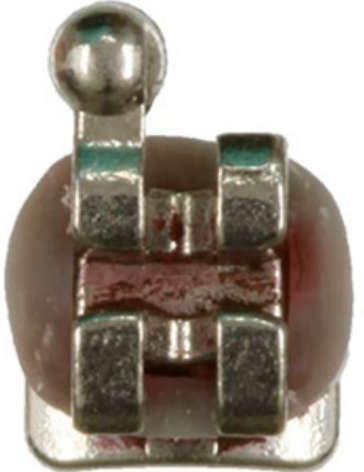

$\mathrm{E}$

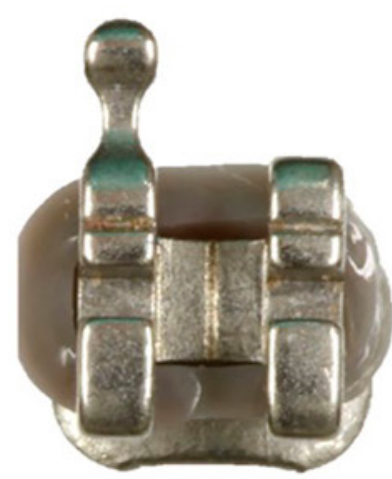

H

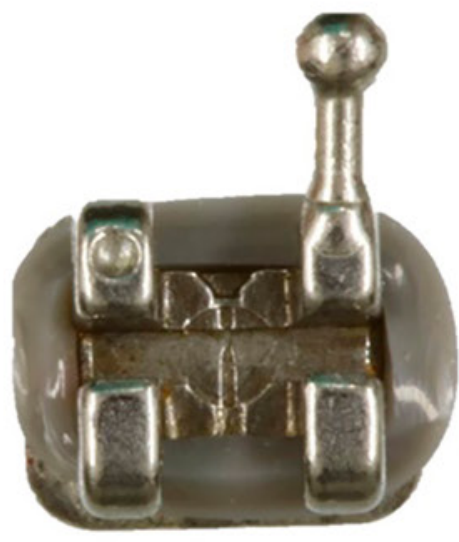

K

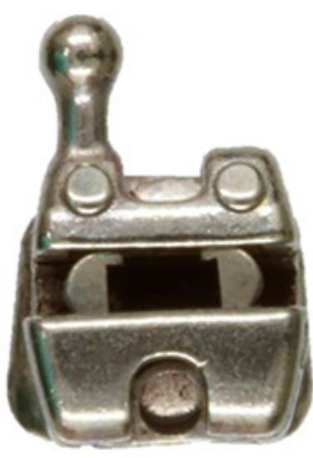

c

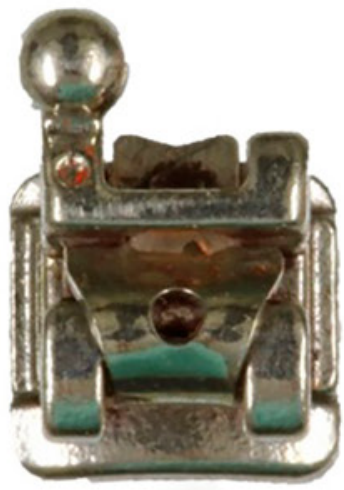

F

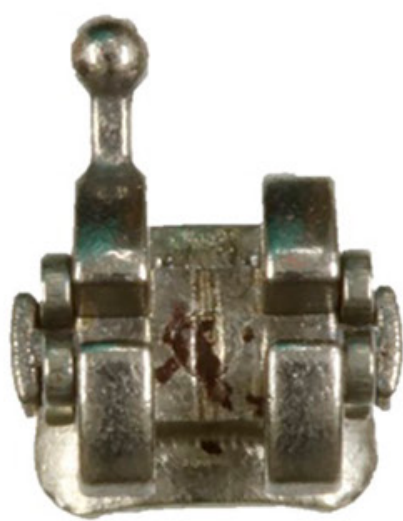

1

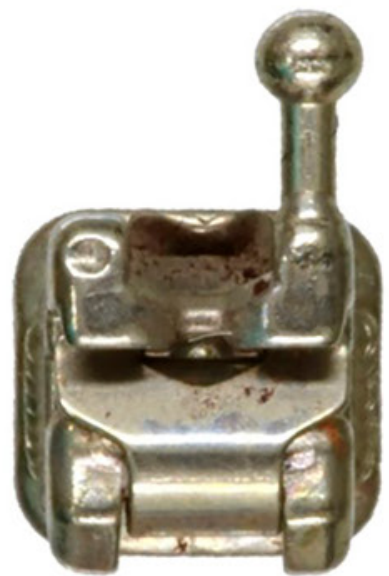

L

Figure 1: Study groups, in relation to commercial brand and ligature type. Legends: A) Abz-Met; B) Abz-Ela; C) Abz-SL; D) Mor-Met; E) Mor-Ela; F) Mor-SL; G) 3M-Met; H) 3M-Ela; I) $3 M-S L ;$ J) GAC-Met; K) GAC-Ela; L) GAC-SL. 
Table 1: Distribution and characterization of study groups in relation to commercial brand, ligature type, nomination and bracket model.

\begin{tabular}{|c|c|c|c|c|}
\hline Brand & Ligature & Nomination & $\mathbf{n}$ & Model \\
\hline \multirow{3}{*}{$\mathrm{Abzil}^{\circledR}$} & Metallic & Abz-Met & 6 & Kirium Roth (0.022-in) \\
\hline & Elastic & Abz-Ela & 6 & Kirium Roth (0.022-in) \\
\hline & Self-ligating & Abz-SL & 6 & Portia Roth (0.022-in) \\
\hline \multirow{3}{*}{ Morelli ${ }^{\circledR}$} & Metallic & Mor-Met & 6 & Standard Roth (0.022-in) \\
\hline & Elastic & Mor-Ela & 6 & Standard Roth (0.022-in) \\
\hline & Self-ligating & Mor-SL & 6 & SLI Roth (0.022-in) \\
\hline \multirow{3}{*}{$3 M$ Unitek $^{\circledR}$} & Metallic & 3M-Met & 6 & Victory Series Roth (0.022-in) \\
\hline & Elastic & 3M-Ela & 6 & Victory Series Roth (0.022-in) \\
\hline & Self-ligating & $3 M-S L$ & 6 & Smartclip Roth (0.022-in) \\
\hline \multirow{3}{*}{$\mathrm{GAC}^{\circledR}$} & Metallic & GAC-Met & 6 & Ovation Roth (0.022-in) \\
\hline & Elastic & GAC-Ela & 6 & Ovation Roth (0.022-in) \\
\hline & Self-ligating & GAC-SL & 6 & In-Ovation Roth (0.022-in) \\
\hline
\end{tabular}

\section{SALIVA COLLECTION}

Saliva was collected from three voluntary donors and subsequently centrifuged and sterilized by vacuum filtration. The donors were 30 to 36 years old, had good oral health and, at the time of the collection, had fasted for eight hours without having brushed their teeth. In addition, they had not undergone professional cleaning or antibiotic therapy in the three months prior to collection, nor had they had caries or periodontal disease at the time. After collection, the saliva was kept on ice until its use.

\section{STREPTOCOCCUS MUTANS BIOFILM FORMATION}

A Streptococcus mutans UA159 strain was initially reactivated from stock cultures in liquid BHI (Brain-heart infusion) medium for 18 to 24 hours at $37^{\circ} \mathrm{C}, 5 \% \mathrm{CO}_{2^{\prime}}$ and then cultured in $\mathrm{BHI}$ 
agar plates. After bacterial growth, the individual colonies were removed with the aid of a platinum loop, and then suspended in a solution with liquid BHI medium, to perform the bacterial growth curve. After the Streptococcus mutans (SM) culture had reached the LOG phase (OD $=0.5 \mathrm{~nm}$ to $660 \mathrm{~nm}$ ), it was homogenized, and a $100 \mu \mathrm{L}$ volume of the SM suspension was inoculated into $100 \mathrm{~mL}$ BHI medium plus 1\% sucrose, in order to obtain a bacterial concentration of approximately 1 to $2 \times 10^{5} \mathrm{CFU} / \mathrm{mL}$ (CLSI, 2012) ${ }^{32}$, which would later be used as an inoculum for biofilm formation in brackets.

\section{DESCRIPTION OF THE EXPERIMENT}

Into a 96-well plate, the previously sterilized brackets were carefully immersed in saliva for one hour, so that each bracket would occupy a well. After this period, the saliva was removed, the brackets were washed with phosphate buffer solution (PBS), and added to another plate along with $200 \mu \mathrm{L}$ (in each well) of the bacterial suspension prepared as described in Figure 2. After inoculation, the plate was kept at $37^{\circ} \mathrm{C}, 5 \% \mathrm{CO}_{2}$ for 72 hours.

Posteriorly, the brackets were removed from the wells and carefully transferred to Eppendorf-type tubes (Eppendorf ${ }^{\circledR}$, Hamburg, Germany) containing $1 \mathrm{~mL}$ of PBS, which were sonicated for 10 minutes, to separate bacteria adhered to biofilm from the brackets. 


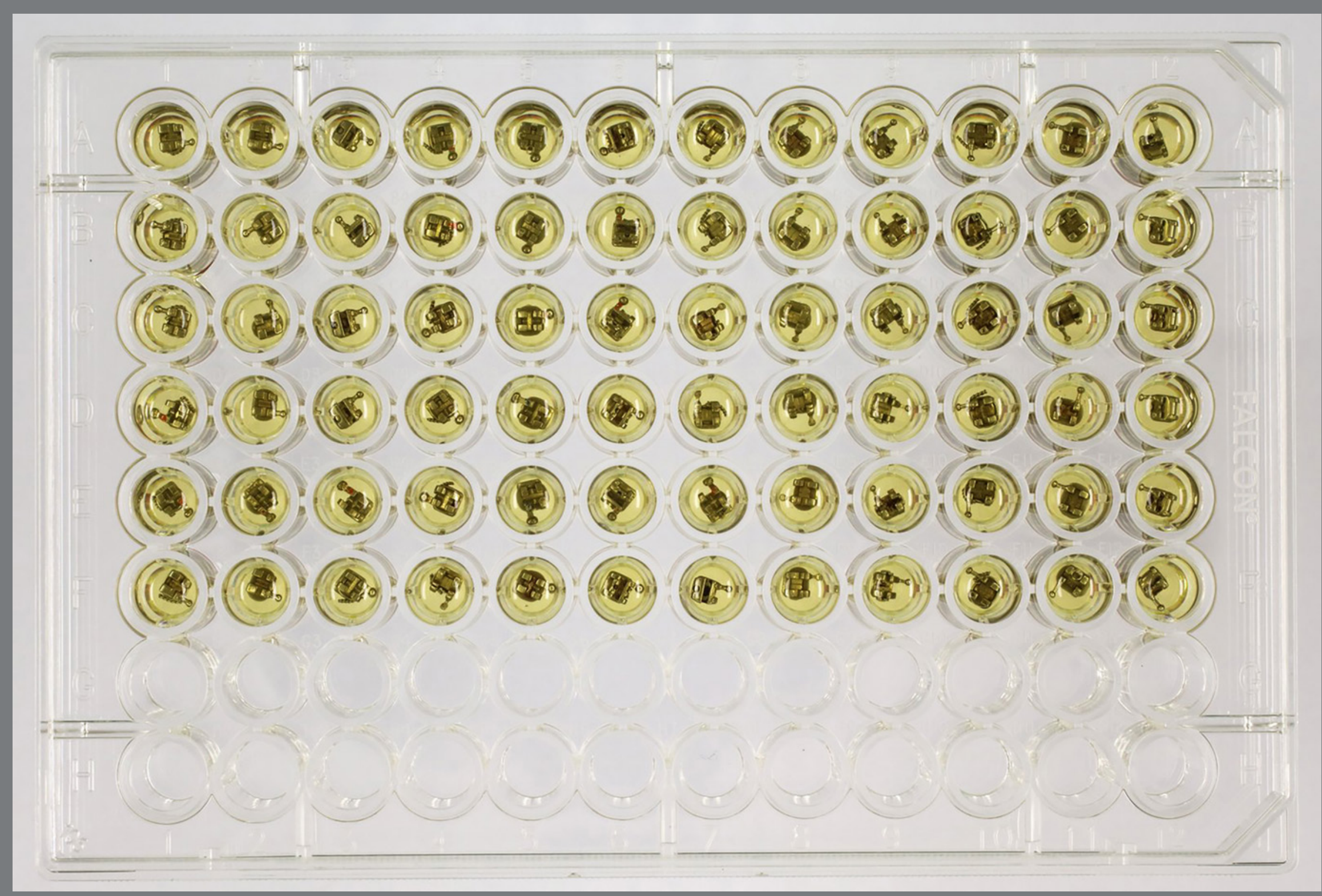

Figure 2: Brackets immersed during experiment.

To quantify bacterial adherence, serial dilution and plating on BHI agar plates added with sheep's blood were performed. Colony Forming Units (CFU) counts were performed after 48 hours of bacterial growth on the plates at $37^{\circ} \mathrm{C}$ and $5 \% \mathrm{CO}_{2}$. Thus, the higher the number of CFUs, the greater the number of viable bacteria that adhered to the bracket surface throughout the experiment. 


\section{STATISTICAL ANALYSIS}

Data were initially evaluated for their distribution and, after finding non-normal distributions; the groups were compared with the application of the Kruskal-Wallis test. If statistical significance was detected, any differences in pairwise comparisons were verified by applying the Dunn post-hoc test. Statistical significance was set at $5 \%(p<0.05)$.

\section{RESULTS}

Comparative analyzes between types of bracket/ligatures, regardless of the brand are depicted in the Figure 3. Self-ligating brackets (mean: $2.5 \times 10^{6}$; standard deviation: $5.8 \times 10^{6}$; median: $1.9 \times 10^{6}$; quartile $1: 7.0 \times 10^{5}$; quartile $3: 8.5 \times 10^{6}$ ) presentedasignificantly lower amounts of CFU/mL $(p<0.05)$, when compared to conventional brackets with metallic (mean: $1.3 \times 10^{7}$; standard-deviation: $1.4 \times 10^{7}$; median: $9.0 \times 10^{6}$; quartile 1: $3.1 \times 10^{6}$; quartile 3: $1.6 \times 10^{7}$ ) and elastic (mean: $1.5 \times 10^{6}$; standard-deviation: $1.5 \times 10^{7}$; median: $1.0 \times 10^{7}$; quartile $1: 4.5 \times 10^{6}$; quartile 3: $1.5 \times 10^{7}$ ) ligatures, which might suggest that, overall, biofilm accumulation in self-ligating brackets is lower.

However, no statistically significant differences were found between the bracket / ligature types in comparisons performed within each commercial brand individually, except for the Abzil ${ }^{\circledR}$ bracket models (Table 2). In the paired comparison between Abz-SL and Abz-Ela, a significantly higher amount of CFU/mL was observed for the latter. In addition, when the Abz-SL and 


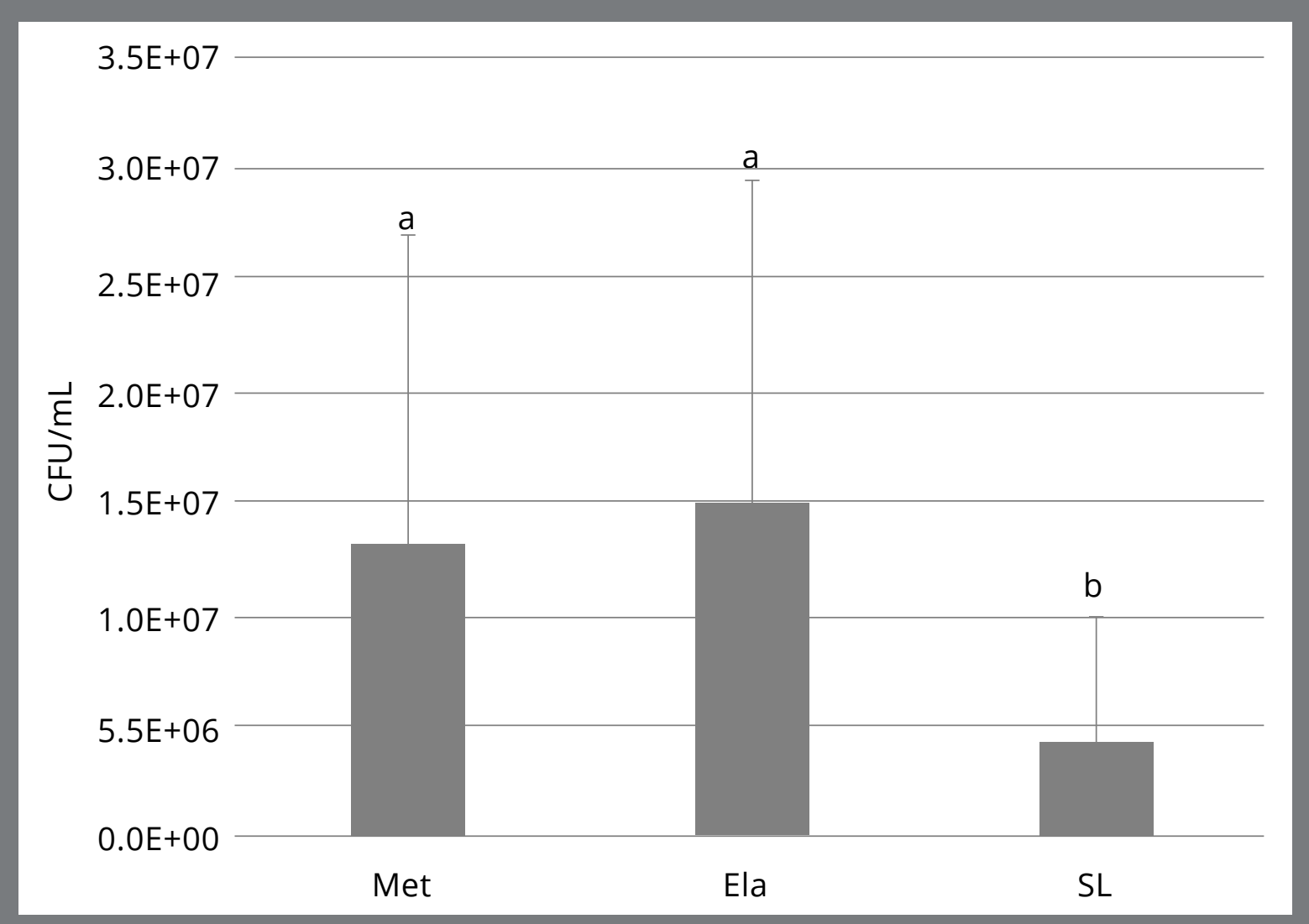

Figure 3: Analysis of biofilm formation by CFU/mL counting in the different types of brackets/ ligatures. Different letters mean statistically significant differences.

Abz-Met groups were compared, significantly higher amounts of CFU/mL were observed for Abz-Met; but without significant differences when these and the conventional brackets with elastic ligatures (Abz-Ela) were compared with each other (Table 2).

As for the comparisons performed between commercial brands, considering each bracket / ligature type, no significant differences were observed for brackets with metallic $(p=0.4852)$ or elastic ( $p=0.7120)$ ligatures. However, among self-ligating brackets, significant differences were observed $(p=0.0474)$, and the $\mathrm{GAC}^{\circledR}$ brackets presented relatively higher bacterial adhesion rates. However, when the groups were compared pairwise, this difference only reached statistically significance when GAC-SL was compared to Abz-SL $(p=0.0071)$. 
Table 2: Descriptive and inferential statistics comparing study groups.

\begin{tabular}{|c|c|c|c|c|c|c|}
\hline Groups & $\begin{array}{l}\text { UFC/mL } \\
\text { (median) }\end{array}$ & $\begin{array}{l}\text { UFC/mL } \\
\text { (Q1/Q3) }\end{array}$ & $\begin{array}{c}\mathrm{UFC} / \mathrm{mL} \\
\text { (mean/SD) }\end{array}$ & $\begin{array}{l}\text { Kruskal-Wallis } \\
\text { (p-valor) }\end{array}$ & \multicolumn{2}{|c|}{ Dunn (p-valor) } \\
\hline Abz-Met & $7.6 \times 10^{6}$ & $\begin{array}{c}2.0 \times 10^{5} / \\
4.3 \times 10^{7}\end{array}$ & $\begin{array}{l}1.7 \times 10^{7} / \\
\left(2.1 \times 10^{7}\right)\end{array}$ & \multirow{3}{*}{$p=0.0058$} & Abz-Met vs. Abz-Ela & $p=0.9784$ \\
\hline Abz-Ela & $6.0 \times 10^{6}$ & $\begin{array}{l}1.1 \times 10^{6} / \\
4.6 \times 10^{7}\end{array}$ & $\begin{array}{l}1.8 \times 10^{7} / \\
\left(2.3 \times 10^{7}\right)\end{array}$ & & Abz-Met vs. Abz-SL & $p=0.0063$ \\
\hline Abz-SL & $7.0 \times 10^{5}$ & $\begin{array}{l}5.5 \times 10^{5} / \\
5.1 \times 10^{6}\end{array}$ & $\begin{array}{l}2.1 \times 10^{6} / \\
\left(3.6 \times 10^{6}\right)\end{array}$ & & Abz-Ela vs. Abz-SL & $p=0.0069$ \\
\hline Mor-Met & $1.2 \times 10^{7}$ & $\begin{array}{l}7.5 \times 10^{6} / \\
1.8 \times 10^{7}\end{array}$ & $\begin{array}{l}1.3 \times 10^{7} / \\
\left(5.0 \times 10^{6}\right)\end{array}$ & \multirow{3}{*}{$p=0.6842$} & & \\
\hline Mor-Ela & $8.8 \times 10^{6}$ & $\begin{array}{l}5,0 \times 10^{6} / \\
2.0 \times 10^{7}\end{array}$ & $\begin{array}{l}1.1 \times 10^{7} / \\
\left(8.4 \times 10^{6}\right)\end{array}$ & & & \\
\hline Mor-SL & $7.0 \times 10^{6}$ & $\begin{array}{l}1,7 \times 10^{6} / \\
1.9 \times 10^{7}\end{array}$ & $\begin{array}{l}9.4 \times 10^{6} / \\
\left(8.9 \times 10^{6}\right)\end{array}$ & & & \\
\hline 3M-Met & $9.0 \times 10^{6}$ & $\begin{array}{c}4.6 \times 10^{6} / \\
1.9 \times 10^{7}\end{array}$ & $\begin{array}{l}1.1 \times 10^{7} / \\
\left(7.4 \times 10^{6}\right)\end{array}$ & \multirow{3}{*}{$p=0.7720$} & & \\
\hline 3M-Ela & $9.5 \times 10^{6}$ & $\begin{array}{l}4.0 \times 10^{6} / \\
2.4 \times 10^{7}\end{array}$ & $\begin{array}{l}1.3 \times 10^{7} / \\
\left(1.1 \times 10^{7}\right)\end{array}$ & & & \\
\hline $3 M-S L$ & $2.7 \times 10^{6}$ & $\begin{array}{l}9.5 \times 10^{5} / \\
9.2 \times 10^{6}\end{array}$ & $\begin{array}{l}4.3 \times 10^{6} / \\
\left(4.1 \times 10^{6}\right)\end{array}$ & & & \\
\hline GAC-Met & $5.3 \times 10^{6}$ & $\begin{array}{l}1.9 \times 10^{6} / \\
3.0 \times 10^{7}\end{array}$ & $\begin{array}{l}1.2 \times 10^{7} / \\
\left(1.9 \times 10^{7}\right)\end{array}$ & \multirow{3}{*}{$p=0.7369$} & & \\
\hline GAC-Ela & $1.4 \times 10^{7}$ & $\begin{array}{l}8.0 \times 10^{6} / \\
3.2 \times 10^{7}\end{array}$ & $\begin{array}{l}1.8 \times 10^{7} / \\
\left(1.6 \times 10^{7}\right)\end{array}$ & & & \\
\hline GAC-SL & $1.7 \times 10^{6}$ & $\begin{array}{l}3.7 \times 10^{5} / \\
2.0 \times 10^{6}\end{array}$ & $\begin{array}{l}1.4 \times 10^{6} / \\
\left(8.0 \times 10^{5}\right)\end{array}$ & & & \\
\hline
\end{tabular}

\section{DISCUSSION}

This study aimed at evaluating SM adherence in self-ligating and conventional brackets of different models and ligature types, through the conduction of an in vitro experimental design and microbiological analyses. SM strains were used in this study, as this is considered to be the mostimportantmicroorganism responsible 
for caries and enamel demineralization. ${ }^{33}$ Furthermore, several studies have already observed that SM levels significantly increase during orthodontic treatment. ${ }^{34,35}$

For this study, it was also decided to test commercially relevant brackets, which are usually available for orthodontists. Hence, although this research has been conducted according to a laboratory methodology - and, therefore, with restricted practical applicability - , the preset results can still serve as a useful parameter to help clinicians choosing their material. Thus, in vitro studies might be quite relevant, due to the application of rigorous control during the conduction of experiments; and, therefore, they also provide adequate power to evaluate the influences to be potentially exerted by variables, individually. Therefore, since in vitro studies are originally conceived to create controlled experimental scenarios, sample calculation may not be considered as mandatory. Still, in order to cover variability, this experiment was performed in triplicate.

One of the results demonstrated that, when bracket / ligature types were compared, without considering the commercial brands, significantly lower bacterial adhesion was observed for the self-ligating brackets. This fact refutes a previous research ${ }^{36}$ that, despite having found differences between bracket models, did not attribute higher degrees of bacterial adhesion to self-ligating brackets. Presumably, such disagreement between 
results may be associated with the self-ligating bracket commercial brands analyzed in that study, ${ }^{36}$ which differed from those evaluated here.

Thus, it is important to emphasize that any attempt to compare the present results with the ones provided by literature should ideally be made considering the specific bracket models tested here. In this sense, Garcez et $\mathrm{al}^{37}$ evaluated $\mathrm{GAC}^{\circledR}$ brackets according to microbiological methodology. Unlike the results obtained here, however, those authors ${ }^{37}$ observed that conventional brackets with elastic ligatures adhered significantly more biofilm than self-ligating brackets or brackets with metallic ligatures. Although the present data also indicated a tendency for greater bacterial adhesion for the elastic ligature brackets, this difference was not statistically significant in the analysis of $\mathrm{GAC}{ }^{\circledR}$ brackets.

Tupinambá et al $^{38}$ also comparatively evaluated conventional and self-ligating brackets - in this case, from Morelli ${ }^{\circledR}$ commercial brand. While no significant differences were observed by the analysis employed here, the authors of that study ${ }^{38}$ found lower bacterial adhesion to conventional brackets. However, these were processed without the presence of any type of ligature, either metallic or elastic. That might have been one of the reasons why results from both studies are not in accordance. 
By analyzing potential differences between the types of ligatures for each brand individually, differences were statistically significant only for the Abzil ${ }^{\circledR}$ models, with self-ligating having lower biofilm adhesion than the conventional brackets. Whereas one of the major appeals used by self-ligating bracket manufacturers refers to the lower capacity of this type of bracket to accumulate biofilm, ${ }^{29,30}$ the data from this study indicated advantages only for $\mathrm{Abzil}^{\circledR}$ commercial brand.

Among the four types of self-ligating brackets tested in this study, GAC ${ }^{\circledR}$ showed the highest SM adhesion rates, especially when compared the Abzil ${ }^{\circledR}$ self-ligating brackets. Thus, the most relevant results of this study indicate, on the one hand, the potential superiority of $\mathrm{Abzil}^{\circledR}$ self-ligating brackets among the other models from the same brand; and, on the other hand, possible inferiority of the $\mathrm{GAC}^{\circledR}$ brackets among the self-ligating bracket models tested in this study.

However, despite possible differences, the results demonstrated here have limited clinical applicability, as already mentioned. Clinical studies still present controversial conclusions regarding the influence of bracket design (conventional versus self-ligating) on SM colony formation and adhesion ${ }^{39}$ or upon oral microbiota alteration. ${ }^{40}$ However, according to data collected by a systematic review, ${ }^{41}$ the periodontal status of orthodontic patients seems to remain equally altered, whether by the use of conventional or self-ligating brackets. Such tendency 
could be noticed, even in a study ${ }^{42}$ evaluating the clinical performance of $A$ bzil ${ }^{\circledR}$ self-ligating brackets, which presented, in this study, the best performance in a laboratorial context.

Thus, based on the data collected in this study, further attempts at controlled clinical studies are encouraged. In addition to including commercially available bracket brands, future studies should also include clinically relevant outcomes, related mainly to the periodontal conditions resulting from the installation of conventional and self-ligated bracket models, and the occurrence of white spot lesions.

\section{CONCLUSIONS}

Self-ligating brackets are likely to present lower rates of biofilm adhesion, particularly $\mathrm{Abzi}^{\circledR}$ and $\mathrm{GAC}^{\circledR}$ self-ligating brackets. While Abzil ${ }^{\circledR}$ self-ligating brackets are likely to present lower rates of SM biofilm adhesion, when compared to conventional brackets of the same brand (associated with elastic or metallic ligatures), GAC ${ }^{\circledR}$ self-ligating brackets are less likely to accumulate biofilm, especially if compared to Abzi ${ }^{\circledR}$ self-ligating brackets. 
AUTHORS CONTRIBUTIONS

Murilo F. Neuppmann Feres (MFNF)

Fernanda Vicioni Marques (FVM)

Fábio Lourenço Romano (FLR)

Conception or design of the study:

MFNF.

Data acquisition, analysis or

interpretation:

MFNF, FVM, FLR, MGR, VMS, ALT, BBS.

Writing the article:

MFNF.
Marina Guimarães Roscoe (MGR)

Vinícius Matsuzaki de Souza (VMS)

Aline Lira Torneri (ALT)

Bruno Bueno-Silva (BBS)

Critical revision of the article:

MFNF, FVM, FLR, MGR, VMS, ALT, BBS.

Final approval of the article:

MFNF, FVM, FLR, MGR, VMS, ALT, BBS.

Overall responsibility:

MFNF.

The authors report no commercial, proprietary or financial interest in the products or companies described in this article.

\section{REFERENCES}

1. Henrikson T. Temporomandibular disorders and mandibular function in relation to Class II malocclusion and orthodontic treatment. A controlled, prospective and longitudinal study. Swed Dent J Suppl. 1999;134:1-144.

2. Woon SC, Thiruvenkatachari B. Early orthodontic treatment for Class III malocclusion: A systematic review and meta-analysis. Am J Orthod Dentofacial Orthop. 2017 Jan;151(1):28-52.

3. Tai K, Park JH. Improvement of facial profile by nonextraction orthodontic treatment with temporary skeletal anchorage devices and visual treatment objectives. Am J Orthod Dentofacial Orthop. 2018 Nov;154(5):708-17. 
4. Ferrando-Magraner E, García-Sanz V, Bellot-Arcís C, MontielCompany JM, Almerich-Silla JM, Paredes-Gallardo V. Oral healthrelated quality of life of adolescents after orthodontic treatment. A systematic review. J Clin Exp Dent. 2019 Feb 1;11(2):e194-e202.

5. Bollen AM, Cunha-Cruz J, Bakko DW, Huang GJ, Hujoel PP. The effects of orthodontic therapy on periodontal health: $a$ systematic review of controlled evidence. J Am Dent Assoc. 2008 Apr;139(4):413-22.

6. Weltman B, Vig KW, Fields HW, Shanker S, Kaizar EE. Root resorption associated with orthodontic tooth movement: a systematic review. Am J Orthod Dentofacial Orthop. 2010 Apr;137(4):462-76; discussion 12A.

7. Zahrowski J, Jeske A. Apical root resorption is associated with comprehensive orthodontic treatment but not clearly dependent on prior tooth characteristics or orthodontic techniques. J Am Dent Assoc. 2011;142(1):66-8.

8. Alfuriji S, Alhazmi N, Alhamlan N, Al-Ehaideb A, Alruwaithi $M$, Alkatheeri $N$, et al. The effect of orthodontic therapy on periodontal health: a review of the literature. Int J Dent. 2014;2014:585048.

9. Castro LO, Castro IO, de Alencar AH, Valladares-Neto J, Estrela C. Cone beam computed tomography evaluation of distance from cementoenamel junction to alveolar crest before and after nonextraction orthodontic treatment. Angle Orthod. 2016 Jul;86(4):543-9. 
10. Derks A, Katsaros C, Frencken JE, van't Hof MA, Kuijpers-Jagtman AM. Caries-inhibiting effect of preventive measures during orthodontic treatment with fixed appliances. A systematic review. Caries Res. 2004 Sep-Oct;38(5):413-20.

11. Ren $Y$, Jongsma MA, Mei $L$, van der Mei HC, Busscher $H J$. Orthodontic treatment with fixed appliances and biofilm formation--a potential public health threat? Clin Oral Investig. 2014 Sep;18(7):1711-8.

12. van Gastel J, Quirynen M, Teughels W, Pauwels M, Coucke W, Carels C. Microbial adhesion on different bracket types in vitro. Angle Orthod. 2009 Sep;79(5):915-21.

13. Jongsma MA, Pelser FD, van der Mei HC, Atema-Smit J, van de Belt-Gritter $B$, Busscher $\mathrm{HJ}$, et al. Biofilm formation on stainless steel and gold wires for bonded retainers in vitro and in vivo and their susceptibility to oral antimicrobials. Clin Oral Investig. 2013 May;17(4):1209-18.

14. Eid HA, Assiri HA, Kandyala R, Togoo RA, Turakhia VS. Gingival enlargement in different age groups during fixed Orthodontic treatment. J Int Oral Health. 2014 Feb;6(1):1-4.

15. Sinclair PM, Berry CW, Bennett $\mathrm{CL}$, Israelson $\mathrm{H}$. Changes in gingiva and gingival flora with bonding and banding. Angle Orthod. 1987 Oct;57(4):271-8.

16. Paolantonio M, Festa F, di Placido G, D'Attilio M, Catamo G, Piccolomini R. Site-specific subgingival colonization by Actinobacillus actinomycetemcomitans in orthodontic patients. Am J Orthod Dentofacial Orthop. 1999 Apr;115(4):423-8. 
17. Ristic M, Vlahovic Svabic M, Sasic M, Zelic O. Clinical and microbiological effects of fixed orthodontic appliances on periodontal tissues in adolescents. Orthod Craniofac Res. 2007 Nov;10(4):187-95.

18. Heintz SD, Georg P. Oral health for the orthodontic patients. Philadelphia: Mosby; 1999. p. 2-9, 94-7.

19. Evrenol BI, Kucukkeles N, Arun T, Yarat A. Fluoride release capacities of four different orthodontic adhesives. J Clin Pediatr Dent. 1999 Summer;23(4):315-9.

20. Derks A, Katsaros C, Frencken JE, van't Hof MA, Kuijpers-Jagtman AM. Caries-inhibiting effect of preventive measures during orthodontic treatment with fixed appliances. A systematic review. Caries Res. 2004 Sep-Oct;38(5):413-20.

21. Nelson-Filho P, Olmedo LY, Andrucioli MC, Saraiva Mda C, Matsumoto MA, de Queiroz AM, et al. Use of the checkerboard DNA-DNA hybridisation technique for in vivo detection of cariogenic microorganisms on metallic brackets, with or without use of an antimicrobial agent. J Dent. 2011 Jul;39(7):513-7.

22. Nelson-Filho P, Valdez RM, Andrucioli MC, Saraiva MC, Feres M, Sorgi CA, et al. Gram-negative periodontal pathogens and bacterial endotoxin in metallic orthodontic brackets with or without an antimicrobial agent: an in-vivo study. Am J Orthod Dentofacial Orthop. 2011 Dec;140(6):e281-7.

23. Nelson-Filho P, Carpio-Horta KO, Andrucioli MC, Feres M, Bezerra da Silva RA, Garcia Paula-Silva FW, et al. Molecular detection of Aggregatibacter actinomycetemcomitans on metallic brackets by the checkerboard DNADNA hybridization technique. Am J Orthod Dentofacial Orthop. 2012 Oct;142(4):481-6. 
24. Andrucioli MC, Nelson-Filho P, Matsumoto MA, Saraiva MC, Feres $\mathrm{M}$, de Figueiredo LC, et al. Molecular detection of in-vivo microbial contamination of metallic orthodontic brackets by checkerboard DNA-DNA hybridization. Am J Orthod Dentofacial Orthop. 2012 Jan;141(1):24-9.

25. Freitas AO, Marquezan M, Nojima Mda C, Alviano DS, Maia LC. The influence of orthodontic fixed appliances on the oral microbiota: a systematic review. Dental Press J Orthod. 2014 MarApr;19(2):46-55.

26. Gottlieb EL, Wildman AJ, Hice TL, Lang HM, Lee IF, Strauch EC Jr. The Edgelok bracket. J Clin Orthod. 1972 Nov;6(11):613-23 passim.

27. Gottlieb EL, Wildman AJ, Hice TL, Lang HM, Lee IF, Strauch EC Jr. The Edgelok bracket. J Clin Orthod. 1972 Nov;6(11):613-23 passim.

28. Harradine NW, Birnie DJ. The clinical use of Activa self-ligating brackets. Am J Orthod Dentofacial Orthop. 1996 Mar;109(3):319-28.

29. Forsberg CM, Brattström V, Malmberg E, Nord CE. Ligature wires and elastomeric rings: two methods of ligation, and their association with microbial colonization of Streptococcus mutans and lactobacilli. Eur J Orthod. 1991 Oct;13(5):416-20.

30. Paduano S, Cioffi I, lodice G, Rapuano A, Silva R. Time efficiency of self-ligating vs conventional brackets in orthodontics: effect of appliances and ligating systems. Prog Orthod. 2008;9(2):74-80. 
31. do Nascimento LE, de Souza MM, Azevedo AR, Maia LC. Are self-ligating brackets related to less formation of Streptococcus mutans colonies? A systematic review. Dental Press J Orthod. 2014 Jan-Feb;19(1):60-8.

32. CLSI. Methods for Antimicrobial Susceptibility Testing of Anaerobic Bacteria. 8th ed. CLSI standard M11. Wayne, PA: Clinical and Laboratory Standards Institute; 2012.

33. García-Godoy F, Hicks MJ. Maintaining the integrity of the enamel surface: the role of dental biofilm, saliva and preventive agents in enamel demineralization and remineralization. J Am Dent Assoc. 2008 May;139 Suppl:25S-34S.

34. Scheie AA, Arneberg P, Krogstad O. Effect of orthodontic treatment on prevalence of Streptococcus mutans in plaque and saliva. Scand J Dent Res. 1984 Jun;92(3):211-7.

35. Chang HS, Walsh LJ, Freer TJ. The effect of orthodontic treatment on salivary flow, $\mathrm{pH}$, buffer capacity, and levels of mutans streptococci and lactobacilli. Aust Orthod J. 1999 Apr;15(4):229-34.

36. van Gastel J, Quirynen M, Teughels W, Coucke W, Carels C. Influence of bracket design on microbial and periodontal parameters in vivo. J Clin Periodontol. 2007 May;34(5):423-31.

37. Garcez AS, Suzuki SS, Ribeiro MS, Mada EY, Freitas AZ, Suzuki H. Biofilm retention by 3 methods of ligation on orthodontic brackets: a microbiologic and optical coherence tomography analysis. Am J Orthod Dentofacial Orthop. 2011 Oct;140(4):e193-8. 
38. Tupinambá RA, Claro CAA, Pereira CA, Nobrega CJP, Claro APRA. Bacterial adhesion on conventional and self-ligating metallic brackets after surface treatment with plasma-polymerized hexamethyldisiloxane. Dental Press J Orthod. 2017 Jul-Aug;22(4):77-85.

39. Longoni JN, Lopes BMV, Freires IA, Dutra KL, Franco A, Paranhos LR. Self-ligating versus conventional metallic brackets on Streptococcus mutans retention: a systematic review. Eur J Dent. 2017 Oct-Dec;11(4):537-47.

40. Lucchese A, Bondemark L, Marcolina M, Manuelli M. Changes in oral microbiota due to orthodontic appliances: a systematic review. J Oral Microbiol. 2018 Jul 3;10(1):1476645.

41. Arnold S, Koletsi D, Patcas R, Eliades T. The effect of bracket ligation on the periodontal status of adolescents undergoing orthodontic treatment. A systematic review and meta-analysis. J Dent. 2016 Nov;54:13-24.

42. Cardoso M de A, Saraiva PP, Maltagliati LA, Rhoden FK, Costa CC, Normando D, Capelozza Filho L. Alterations in plaque accumulation and gingival inflammation promoted by treatment with self-ligating and conventional orthodontic brackets. Dental Press J Orthod. 2015 MarApr;20(2):35-41. 